\title{
Epidemiological study of food allergy in a population of Argentine children
}

\author{
Natalia A. Petriz, M.D..,$c$, Carolina Antonietti, M.D. ${ }^{a}$, Cecilia Parente, M.D. ${ }^{a, c}$, Romina Mehaudy, M.D..,$c$, \\ Mercedes Parrales Villacreses, M.D. ${ }^{a}$, Florencia Ursino, M.D. ${ }^{b, c}$, María B. Jauregui, B.S. ${ }^{c, d}$, \\ Marina Orsi, M.D. ${ }^{b, c}$ and Claudio A. S. Parisi, M.D..$^{a, c, e}$
}

\begin{abstract}
Introduction: Food allergies affect mostly children in their first years of life. Epidemiological data obtained in Argentina are scarce.

Objectives: To determine offending foods and describe the prevalence and characteristics of patients with food allergy in an Argentine pediatric population.

Patients and methods: Observational, retrospective, crosssectional study on patients younger than 18 years.

Results: A total of 321 patients were included; food allergy was confirmed in $64 \%$ (207) of cases. An immunoglobulin E-mediated mechanism was observed in $53 \%$ (109); cow's milk protein allergy, in $68 \%$ (140); egg allergy, in $20 \%$ (41); and anaphylaxis as clinical manifestation, in $12 \%$ (24). The overall prevalence of food allergy was $0.87 \%$ (95\% confidence interval: 0.7-0.9).

Conclusions: The overall prevalence of food allergy was $0.87 \%$. Cow's milk was the main allergen, even among adolescents. Key words: food hypersensitivity, child, adolescent, epidemiology.
\end{abstract}

http: / / dx.doi.org/ 10.5546/ aap.2020.eng.418

To cite: Petriz NA, Antonietti C, Parente C, Mehaudy R, et al. Epidemiological study of food allergy in a population of Argentine children. Arch Argent Pediatr 2020;118(6):418-422.

a. Division of Pediatric Allergy, Service of Clinical Pediatrics, Hospital Italiano de Buenos Aires.

b. Service of Pediatric Gastroenterology, Hospital Italiano de Buenos Aires.

c. Interdisciplinary Service of Food Allergy, Hospital Italiano de Buenos Aires.

d. Division of Nutrition, Hospital Italiano de Buenos Aires.

e. International Life Sciences Institute (ILSI) Argentina Food Allergy Task Force.

E-mail address:

Claudio A. Parisi, M.D.: claudioparisi@gmail.com

Funding: None.

Conflict of interest: None.

Received: 5-31-2020

Accepted: 6-18-2020

\section{INTRODUCTION}

Food allergies are adverse reactions resulting from the immune system activation upon exposure to a food allergen. ${ }^{1}$ The pathophysiological mechanisms involved in food allergy may be immunoglobulin E (IgE)mediated, non-IgE-mediated or cell-mediated and mixed reactions. ${ }^{2}$

New treatments are now available, ${ }^{3}$ but avoiding offending foods and patient and family education are the main recommendations. ${ }^{4}$ Several studies referred that $90 \%$ of allergies are caused by 8 foods (milk, eggs, wheat, soy, peanuts, tree nuts, shellfish, and fish), ${ }^{5}$ many of which are ubiquitous and culturally present in our diet, so avoiding them would have an impact on nutrition, quality of life, and health systems. ${ }^{5-7}$

The food allergen labeling law enacted in Argentina ${ }^{8}$ mentions these 8 foods; however, few studies have described the main offending foods in our country. The first years of life is the period of greatest prevalence; ${ }^{9}$ food allergies have been reported in up to $10 \%$ of preschool children ${ }^{10}$ and are believed to have increased over the last decades.

\section{OBJECTIVES}

To determine offending foods and describe the prevalence and characteristics of patients with food allergy in the study population.

\section{MATERIALS AND METHODS}

This was an observational, cross-sectional study of patients younger than 18 years who were members of the Medical Care Program (health plan, HP) of Hospital Italiano de Buenos Aires (HIBA), Argentina, for the period between January 2007 and January 2017. Inclusion criteria were children and adolescents suspected of food allergy.

A confirmed case of immunoglobulin $\mathrm{E}$ (IgE)-mediated food allergy was defined as patients having a compatible medical history, positive specific IgE (based on serological and/ or patch testing), and positive challenge test 
or clear history of food-induced anaphylaxis. A confirmed case of non-IgE-mediated food allergy was defined if patients had delayed symptoms, mostly gastrointestinal, improvement with diet, and positive challenge test and/or positive patch test and/or endoscopy showing eosinophilic inflammation in the intestinal biopsy and negative serological and/or patch test for specific IgE. A case of suspected and nonconfirmed food allergy was defined if patients had skin reactions and/or gastrointestinal and/ or respiratory symptoms (other than anaphylaxis) related to the consumption of foods which did not test positive in the hypersensitivity reaction test and if the allergy to the suspected food had been ruled out in a challenge test.

Cases were detected through a retrospective search looking for key words in the electronic medical records (EMRs) of patients considering diagnoses, clinical presentation, and treatment that included the terms coded by the SNOMED CT terminology. Results were validated manually by specialists in allergy and immunology and pediatric gastroenterologists, who reviewed EMRs when food allergy was suspected. Data were collected in a standardized manner using an ad hoc form. Demographic characteristics were also obtained from medical records.

\section{Statistical analysis}

Quantitative outcome measures were described as mean and standard deviation or as median and interquartile range, based on the observed distribution, and categorical outcome measures, as absolute frequency and percentage. The Stata software, version 13, was used.

The prevalence of confirmed food allergy and its $95 \%$ confidence interval (CI) was estimated at the end of the study (January 2017), and the number of active members of the HIBA HP who were younger than 18 years was used as denominator. An age subgroup analysis was done to describe the characteristics of patients with food allergy.

\section{Ethical considerations}

This study was conducted in accordance with the regulatory standards for human health research and the Declaration of Helsinki, as amended. The study was approved by the Ethics Committee of Hospital Italiano de Buenos Aires under protocol no. 3228.

\section{RESULTS}

A total of 321 patients with potential food allergy were included (Figure 1). Out of all studied patients, food allergy was confirmed in $64 \%$ (207). The mean age of these patients was 3 years (standard deviation [SD]: 4), and $47 \%$ (98) were females. In relation to the immune mechanism involved, it was IgE-mediated in $53 \%$ (109) and non-IgE-mediated in $47 \%$ (98). Table 1 describes the characteristics and main foods involved in patients with confirmed food allergy. The

FIGURE 1. Flow chart of patient inclusion in the study

23733 members of the HIBA HP younger than 18 years

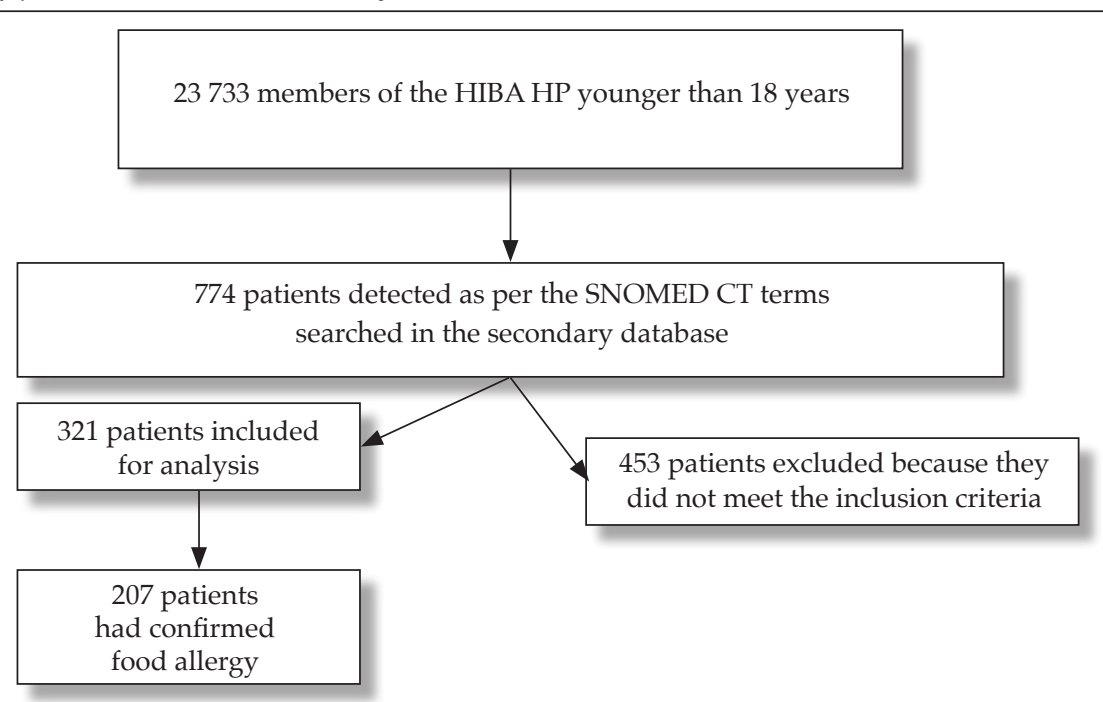

HP: health plan; HIBA: Hospital Italiano de Buenos Aires. 
prevalence of confirmed food allergy was $0.87 \%$ (95\% CI: 0.7-0.9).

Table 2 describes the characteristics of patients with confirmed food allergy based on the age subgroup analysis. The frequency of anaphylaxis increased with age. Cow's milk was shown to be the main offending food across all studied age groups.

\section{DISCUSSION}

In our population, the prevalence of food allergy was $0.87 \%$, lower than that reported in other studies based on self-reporting telephone surveys or specific IgE measurement only, such as the study by Gupta et al. in the United States, which used a survey $(n=38480)$ and estimated that $8 \%$ of children had food allergy, ${ }^{11}$ or the systematic review and meta-analysis by Nwaru

TABLE 1. Characteristics of patients with confirmed food allergy

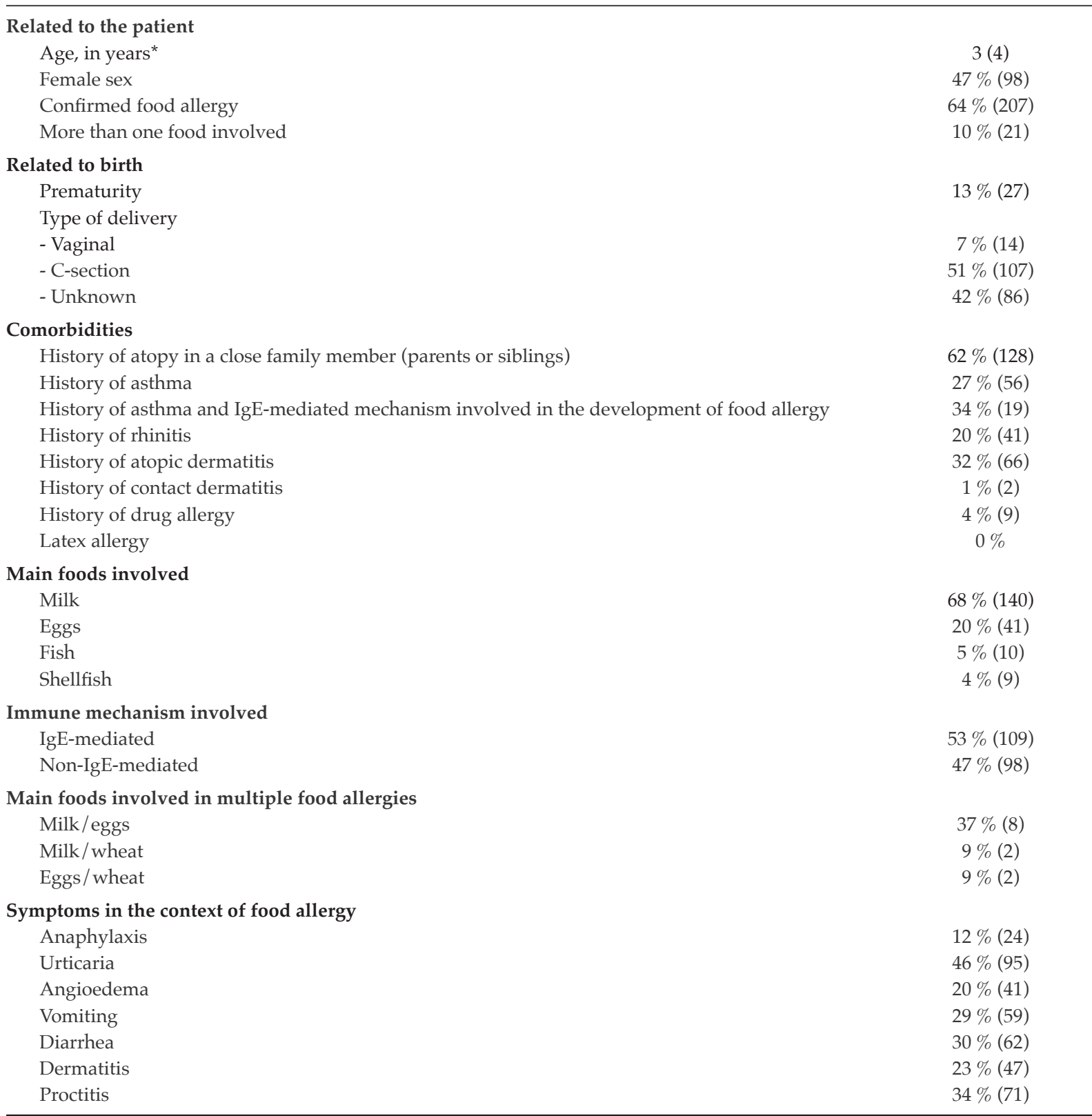

All outcome measures are described as percentage (number of observations).

${ }^{*}$ Mean ( \pm standard deviation); n: number; \%: percentage; IgE: immunoglobulin E. 
et al. in Europe, which compiled 42 studies and showed a prevalence of $6 \%$ (95\% CI: $5.7 \%$ to $6.4 \%) .^{5}$

The prevalence of food allergy in our population was similar to that observed in other studies based on food challenge testing, the gold standard for diagnosis, like the Europrevall, which found a prevalence of $0.9 \% .{ }^{5}$ In our study, food allergy was ruled out in $36 \%$ (114) of suspected cases. It has been demonstrated that the prevalence may be overestimated up to 10 times if diagnosis is not adequately based on case history and specific tests to evidence the pathophysiological mechanism involved. ${ }^{5} \mathrm{~A}$ higher prevalence was observed among preschool children, and the number of positive cases decreased progressively with school age and adolescence, similar to what has been reported in other studies. ${ }^{12}$

Regarding pathophysiological mechanisms,

TABLE 2. Analysis of patients with confirmed food allergy by age subgroup

\begin{tabular}{|c|c|c|c|c|}
\hline Characteristics & $\begin{array}{c}\text { Patients } \\
\text { younger than } 2 \text { years } \\
(\mathrm{N}=153)\end{array}$ & $\begin{array}{c}\text { Patients } \\
\text { aged 3-5 years } \\
(\mathrm{N}=21)\end{array}$ & $\begin{array}{c}\text { Patients } \\
\text { aged 6-11 years } \\
(\mathrm{N}=20) \\
\end{array}$ & $\begin{array}{c}\text { Patients } \\
\text { aged 12-18 years } \\
(\mathrm{N}=13) \\
\end{array}$ \\
\hline $\begin{array}{l}\text { Related to the patient } \\
\text { Female sex }\end{array}$ & $50 \%(76)$ & $52 \%(11)$ & $40 \%(8)$ & $23 \%(3)$ \\
\hline $\begin{array}{l}\text { Related to birth } \\
\text { Prematurity } \\
\text { Type of delivery } \\
\text { - Vaginal } \\
\text { - C-section } \\
\text { - Unknown }\end{array}$ & $\begin{array}{c}3 \%(5) \\
59 \%(91) \\
37 \%(57)\end{array}$ & $\begin{array}{c}14 \%(3) \\
29 \%(6) \\
47 \%(10) \\
24 \%(5)\end{array}$ & $\begin{array}{c}5 \%(1) \\
15 \%(3) \\
20 \%(4) \\
65 \%(13)\end{array}$ & $\begin{array}{c}92 \%(12) \\
8 \%(1) \\
0 \% \\
92 \%(12)\end{array}$ \\
\hline $\begin{array}{l}\text { Comorbidities } \\
\text { History of atopy in a close } \\
\text { family member (parents or siblings) } \\
\text { History of asthma } \\
\text { History of rhinitis } \\
\text { History of atopic dermatitis } \\
\text { History of drug allergy }\end{array}$ & $\begin{array}{c}67 \%(102) \\
25 \%(38) \\
14 \%(21) \\
34 \%(52) \\
4 \%(6)\end{array}$ & $\begin{array}{c}67 \%(14) \\
43 \%(9) \\
38 \%(8) \\
38 \%(8) \\
0 \%(21)\end{array}$ & $\begin{array}{l}35 \%(7) \\
20 \%(4) \\
35 \%(7) \\
25 \%(5) \\
15 \%(3)\end{array}$ & $\begin{array}{c}38 \%(5) \\
38 \%(5) \\
38 \%(5) \\
8 \%(1) \\
0 \%(13)\end{array}$ \\
\hline $\begin{array}{l}\text { Related to food allergy } \\
\text { Immune mechanism } \\
\text { - IgE-mediated } \\
\text { - Non-IgE-mediated }\end{array}$ & $\begin{array}{l}42 \%(65) \\
58 \%(88)\end{array}$ & $\begin{array}{l}71 \%(15) \\
28 \%(6)\end{array}$ & $\begin{array}{l}80 \%(17) \\
20 \%(3)\end{array}$ & $\begin{array}{c}93 \%(12) \\
7 \%(1)\end{array}$ \\
\hline $\begin{array}{l}\text { Food involved } \\
\text { Milk } \\
\text { Eggs } \\
\text { Wheat } \\
\text { Peanuts } \\
\text { Walnuts } \\
\text { Fish } \\
\text { Shellfish } \\
\text { Tree nuts other than peanuts / walnuts } \\
\text { Strawberry } \\
\text { Banana } \\
\text { Kiwi } \\
\text { Tomato }\end{array}$ & $\begin{array}{c}80 \%(123) \\
20 \%(30) \\
3 \%(4) \\
1 \%(1) \\
0 \% \\
0 \% \\
0 \% \\
0 \% \\
1 \%(1) \\
1 \%(1) \\
0 \% \\
0 \%\end{array}$ & $\begin{array}{c}33 \%(7) \\
33 \%(7) \\
0 \% \\
10 \%(2) \\
10 \%(2) \\
10 \%(2) \\
5 \%(1) \\
5 \%(1) \\
0 \% \\
5 \%(1) \\
5 \%(1) \\
5 \%(1)\end{array}$ & $\begin{array}{c}30 \%(6) \\
15 \%(3) \\
0 \% \\
5 \%(1) \\
0 \% \\
30 \%(6) \\
20 \%(4) \\
0 \% \\
0 \% \\
0 \% \\
0 \% \\
0 \%\end{array}$ & $\begin{array}{c}31 \%(4) \\
8 \%(1) \\
8 \%(1) \\
23 \%(3) \\
8 \%(1) \\
8 \%(1) \\
23 \%(3) \\
8 \%(1) \\
0 \% \\
0 \% \\
0 \% \\
0 \%\end{array}$ \\
\hline $\begin{array}{l}\text { Symptoms in the context of food allergy } \\
\text { Anaphylaxis } \\
\text { Urticaria } \\
\text { Angioedema } \\
\text { Vomiting } \\
\text { Diarrhea } \\
\text { Dermatitis } \\
\text { Proctitis } \\
\text { Dysphagia/food impaction }\end{array}$ & $\begin{array}{l}6 \%(11) \\
43 \%(75) \\
85 \%(148) \\
26 \%(46) \\
33 \%(57) \\
24 \%(42) \\
40 \%(70) \\
0 \%\end{array}$ & $\begin{array}{l}29 \%(6) \\
71 \%(15) \\
24 \%(5) \\
38 \%(8) \\
43 \%(9) \\
24 \%(8) \\
14 \%(3) \\
0 \%\end{array}$ & $\begin{array}{l}30 \%(6) \\
65 \%(13) \\
40 \%(8) \\
45 \%(9) \\
20 \%(4) \\
15 \%(3) \\
5 \%(1) \\
0 \%\end{array}$ & $\begin{array}{l}54 \%(7) \\
54 \%(7) \\
54 \%(7) \\
31 \%(4) \\
8 \%(1) \\
15 \%(2) \\
0 \%(13) \\
8 \%(1)\end{array}$ \\
\hline
\end{tabular}

All outcome measures are described as percentage (number of observations).

$\mathrm{n}$ : number; \%: percentage; IgE: immunoglobulin E. 
a slight predominance of non-IgE-mediated allergies was observed among preschoolers, unlike what was observed in schoolchildren and adolescents, among whom IgE-mediated mechanisms prevailed. This is consistent with previous publications. ${ }^{13}$

Skin symptoms were prevalent across all age groups, whereas gastrointestinal symptoms were more common in preschool children, possibly in association with non-IgE-mediated forms. Proctitis was observed in $40 \%$ of preschool children, in agreement with international studies. ${ }^{5}$ Anaphylaxis occurred in $12 \%$ of all patients and in more than half of adolescents, who accounted for the population at higher risk. ${ }^{14}$

In the overall analysis, milk was the prevalent offending food, followed by eggs. When stratified by age, it was observed that, during adolescence, milk was also the main allergen, followed by peanuts, unlike what was reported in other studies. ${ }^{5}$ Milk, eggs, fish, shellfish, peanuts, wheat, and walnuts were the most common foods.

Unlike other studies, ${ }^{5}$ no patients had soy allergy. In addition, $10 \%$ of patients with confirmed diagnosis had allergy to more than one food. Milk and eggs, the most common offending foods, accounted for $37 \%$ of these cases, and this was higher than the percentage observed in other studies, such as the one by Gupta et al., which observed $2.4 \%$ of multiple food allergies. ${ }^{5}$

The main limitation of this study was its retrospective design; however, the availability of EMRs and the fact that patients were managed systematically by an interdisciplinary team allowed to collect data with greater certainty. Another important limitation was that it was conducted at a single facility, so it may not be representative of the entire Argentine population.

\section{CONCLUSIONS}

This study describes an overall prevalence of food allergy of $0.87 \%$, and the most common allergies corresponded to IgE-mediated mechanisms. Cow's milk was one of the main allergens, even among adolescents. Future prospective, multicenter studies are required to confirm these results.

\section{REFERENCES}

1. Boyce JA, Assa'ad A, Burks AW, Jones SM, et al. Guidelines for the Diagnosis and Management of Food Allergy in the United States: summary of the NIAID-sponsored expert panel report. J Am Diet Assoc. 2011;111(1):17-27.

2. Sicherer $\mathrm{SH}$, Sampson HA. Food allergy: A review and update on epidemiology, pathogenesis, diagnosis, prevention, and management. J Allergy Clin Immunol. 2018;141(1):41-58.

3. De Martinis M, Sirufo MM, Suppa M, Ginaldi L. New Perspectives in Food Allergy. Int J Mol Sci. 2020;21(4):1474.

4. Comité Nacional de Alergia, Comité de Pediatría General Ambulatoria y Grupo de Trabajo de Salud Escolar, Sociedad Argentina de Pediatría. Recomendaciones para el manejo del niño con enfermedades alérgicas en la escuela. Arch Argent Pediatr. 2015;113(3):276-85.

5. Nwaru BI, Hickstein L, Panesar SS, Roberts G, et al. Prevalence of common food allergies in Europe: a systematic review and meta-analysis. Allergy. 2014;69(8):992-1007.

6. De Silva D, Geromi M, Panesar SS, Murano A, et al. Acute and long-term management of food allergy: systematic review. Allergy. 2014;69(2):159-67.

7. Lau GY, Patel N, Umasunthar T, Gore C, et al. Anxiety and stress in mothers of food-allergic children. Pediatr Allergy Immunol. 2014;25(3):236-42.

8. ANMAT. Directrices para el rotulado de alérgenos y sustancias capaces de producir reacciones adversas en individuos susceptibles de productos alimenticios envasados. Programa Federal de Control de Alimentos. Buenos Aires: Ministerio de Salud; 2018. [Accessed on: April11 ${ }^{\text {th }}$ 2020]. Available at: http: / / www.anmat.gov.ar/ Alimentos /DIRECTRICES_ROTULADO_ALERGENOS. pdf.

9. Bock SA. Prospective appraisal of complaints of adverse reactions to foods in children during the first 3 years of life. Pediatrics. 1987;79(5):683-8.

10. OsborneNJ,KoplinJJ, MartinPE, Gurrin LC, etal.Prevalence of challenge-proven IgE-mediated food allergy using population-based sampling and predetermined challenge criteria in infants. J Allergy Clin Immunol.2011;127(3):668-76. e1-2.

11. Gupta RS, Springston EE, Warrier MR, Smith B, et al. The prevalence, severity, and distribution of childhood food allergy in the United States. Pediatrics. 2011;128(1):e9-17.

12. Dunlop JH, Keet CA. Epidemiology of Food Allergy. Immunol Allergy Clin North Am. 2018;38(1):13-25.

13. $\mathrm{Yu}$ W, Freeland DMH, Nadeau KC. Food Allergy: immune mechanisms, diagnosis and immunotherapy. Nat Rev Immunol. 2016;16(12):751-65.

14. Loke P, Koplin J, Beck C, Field M, et al. Statewide prevalence of school children at risk of anaphylaxis and rate of adrenaline autoinjector activation in Victorian government schools, Australia. J Allergy Clin Immunol. 2016;138(2):52935. 